\title{
Cannibalism on eggs by walleye pollock Theragra chalcogramma in Shelikof Strait, Gulf of Alaska
}

\author{
Richard D. Brodeur*, Kevin M. Bailey, Suam Kim** \\ Alaska Fisheries Science Center, National Marine Fisheries Service, 7600 Sand Point Way NE, Seattle, Washington 98115 USA
}

\begin{abstract}
A strong density-dependent relationship has been observed for the walleye pollock Theragra chalcogramma population in the Western Gulf of Alaska. It has been suggested that this relationship may be attributed in part to egg cannibalism by the adult spawning stock. This hypothesis was examined by collecting stomach samples of walleye pollock from the main spawning area over 5 yr. Eggs were prevalent in many stomachs, especially in those from the older age classes. The mean number of eggs in the stomachs was not related to the overall amount of food in the stomach but was linearly related to the density of eggs in the water column. Total egg consumption was estimated for 3 years $(1986,1988$, and 1989) and was found to be only a small $(<1)$ percentage of the total egg production. Even during a year (1981) of peak aduit abundance, the total calculated egg consumption was less than $3 \%$ of the total egg production. A passive filtration model provided estimates similar to those observed in the field. We conclude that egg cannibalism alone would not account for the high egg mortalities observed.
\end{abstract}

\section{INTRODUCTION}

The role of density-dependent versus density-independent processes is of fundamental concern to understanding fish population dynamics. In the case of walleye pollock Theragra chalcogramma in the western Gulf of Alaska, a strong negative relationship between the number of new recruits and the spawning stock biomass has been observed (Megrey 1989a, b), suggesting compensation. One mechanism that could lead to such a relationship is cannibalism on young stages (Ricker 1954) and especially on eggs (MacCall 1981). Kim \& Gunderson (1989) suggested that cannibalism on eggs by adult pollock, which are concentrated in the area of maximum egg abundance for prolonged periods of time, may be one cause of the substantial (32 to $35 \% \mathrm{~d}^{-1}$ ) early mortality observed in this population.

Walleye pollock form dense spawning aggregations in the deep troughs of Shelikof Strait during late March and early April (Kim 1987, Hinckley et al. 1991). Extensive patches of eggs are produced which occur at high densities $\left(>50 \mathrm{~m}^{-3}\right)$ relative to most other pelagic

Present addresses:

- Pacific Biological Station, Dept of Fisheries and Oceans, Nanaimo, B.C., Canada V9R 5K3

- Korean Ocean Research \& Development Institute, Polar Research Laboratory, Ansan, PO Box 29, Seoul 425-600, Korea spawning teleosts (Kendall et al. 1987). The eggs incubate at depths between 100 and $300 \mathrm{~m}$ (Kendall \& Kim 1989) for about 2 wk at $5^{\circ} \mathrm{C}$ (Haynes \& Ignell 1983 , Bailey \& Stehr 1986). In areas with dense spawning aggregations, pollock egg patches can exhibit mean densities up to 68 times background levels in the strait and persist for the entire incubation time and well into the larval period (Incze et al, 1989).

Although the highly vulnerable egg and early larval stages are susceptible to predation from a diverse array of invertebrate predators, juvenile and adult fishes may often be the source of the greatest predation mortality (Hunter 1984, Bailey \& Houde 1989). In this paper, we report on the results of $5 \mathrm{yr}$ of pollock stomach sampling during their peak spawning period in the western Gulf of Alaska. We also report egg predation by other pelagic fishes. Using these data, we estimate the contribution of egg cannibalism to the total egg mortality for the Shelikof Strait population, and the potential role of density-dependent egg mortality in population regulation. A passive filtration model is proposed, and predictions are compared with observed data.

\section{MATERIAL AND METHODS}

Data used in this study were gathered aboard the NOAA ship 'Miller Freeman' during surveys of eggs 
and spawning adults from 1985 through 1989. An extensive station grid was initially surveyed in order to locate areas of high egg abundance (Incze et al. 1989). Eggs were sampled using $60 \mathrm{~cm}$ MARMAP bongo gear equipped with $505 \mu \mathrm{m}$ mesh nets, calibrated flow-

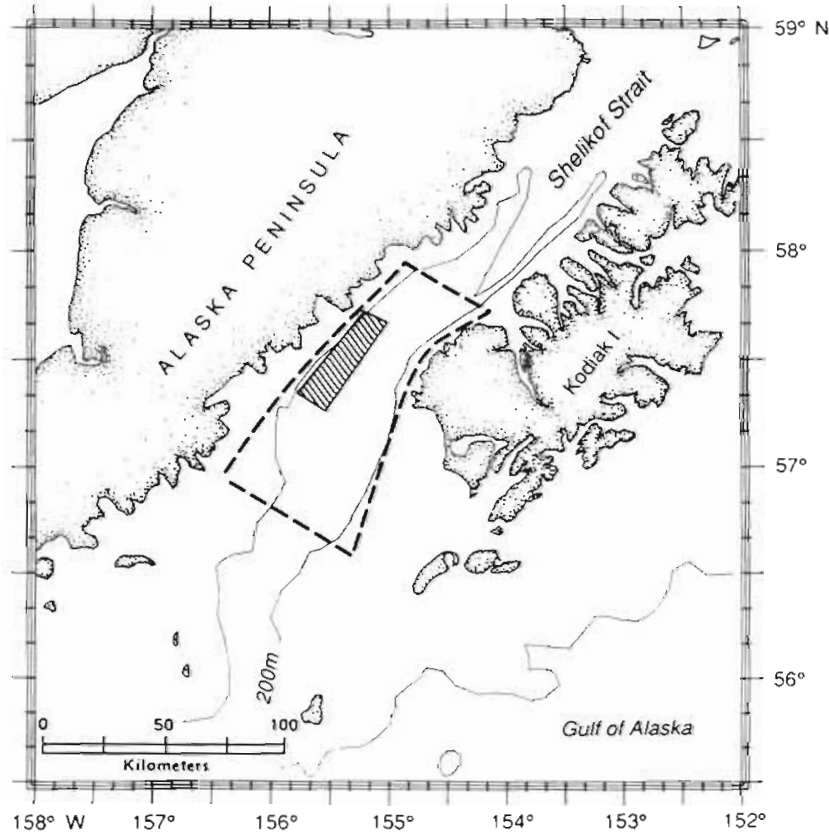

Fig. 1. Location of trawling area (hatched) and area in which adult pollock abundances were estimated (dashed line) from hydroacoustic surveys in Shelikof Strait, Gulf of Alaska meters and a bathykymograph. Tows were doubleoblique from the surface to near bottom. Upon com pletion of the initial sampling, the areas of highest concentration were resampled for egg abundance.

Potential fish predators were collected using Diamond and Marinovich midwater trawls (1985 to 1988) or pelagic rope trawls (1989). All trawl codends were fitted with fine-mesh $(1 \mathrm{~cm})$ liners to capture the full size range of fish predators available. Specific trawl locations (Fig. 1, Table 1) were selected based on the presence of strong acoustic signal readings on a $38 \mathrm{kHz}$ echosounder and chromoscope at the depth of high egg abundance. The trawl was lowered to this depth and towed for short periods of time (generally less than half an hour) before retrieval. The depth of the trawl was monitored using a headrope-mounted netsounder. During years when several hauls were made, an attempt was made to space the collections throughout the diel period (Table 1).

Once the trawl was aboard, a representative subsample of the length distribution of each potential predator was set aside for stomach sampling. Regurgitation effects were minimized by rejecting fish with flaccid stomachs or with food in the oral cavity. From 1985 to 1987, pollock stomachs were examined at sea under a dissecting microscope and eggs were removed and stored in $10 \%$ formalin for later identification and staging. Stomachs of both walleye pollock and eulachon Thaleichthys pacificus, the only other abun-

Table 1. Station and tow data for egg predation sampling by year All times and locations listed are for the start of the tow

\begin{tabular}{|c|c|c|c|c|c|c|c|}
\hline Year & Haul & Date & $\begin{array}{c}\text { Time } \\
(\text { local })(h)\end{array}$ & $\begin{array}{l}\text { Lat. } \\
\text { (N) }\end{array}$ & $\begin{array}{l}\text { Long. } \\
\text { (W) }\end{array}$ & $\begin{array}{c}\text { Gear } \\
\text { depth }(\mathrm{m})\end{array}$ & $\begin{array}{c}\text { Bottom } \\
\text { depth }(\mathrm{m})\end{array}$ \\
\hline 1985 & 1 & $8 \mathrm{Apr}$ & $11: 49$ & $57^{\circ} 44^{\prime}$ & $155^{\circ} 00^{\prime}$ & 237 & 257 \\
\hline \multirow[t]{6}{*}{1986} & 1 & $5 \mathrm{Apr}$ & $12: 39$ & $57^{\circ} 17^{\prime}$ & $155^{\circ} 34^{\prime}$ & 265 & 274 \\
\hline & 2 & $5 \mathrm{Apr}$ & $17: 52$ & $57^{\circ} 15^{\prime}$ & $155^{\circ} 31^{\prime}$ & 183 & 276 \\
\hline & 3 & $9 \mathrm{Apr}$ & $00: 28$ & $57^{\circ} 36^{\prime}$ & $155^{\circ} 18^{\prime}$ & 197 & 298 \\
\hline & 4 & $9 \mathrm{Apr}$ & $01: 44$ & $57^{\circ} 35^{\prime}$ & $155^{\circ} 17^{\prime}$ & 205 & 301 \\
\hline & 5 & $9 \mathrm{Apr}$ & $13: 32$ & $57^{\circ} 34^{\prime}$ & $155^{\circ} 22^{\prime}$ & 152 & 323 \\
\hline & 6 & $9 \mathrm{Apr}$ & $17: 20$ & $57^{\circ} 35^{\prime}$ & $155^{\circ} 19^{\prime}$ & 228 & 311 \\
\hline \multirow[t]{2}{*}{1987} & 1 & $3 \mathrm{Apr}$ & $18: 00$ & $56^{\circ} 27^{\prime}$ & $156^{\circ} 11^{\prime}$ & 225 & 274 \\
\hline & 2 & $3 \mathrm{Apr}$ & $04: 11$ & $57^{\circ} 37^{\prime}$ & $155^{\circ} 18^{\prime}$ & 230 & 284 \\
\hline \multirow[t]{8}{*}{1.988} & 1 & $4 \mathrm{Apr}$ & $14: 01$ & $57^{\circ} 41^{\prime}$ & $155^{\circ} 09^{\prime}$ & 222 & 302 \\
\hline & 2 & $4 \mathrm{Apr}$ & $15: 24$ & $57^{\circ} 40^{\prime}$ & $155^{\circ} 12^{\prime}$ & 210 & 298 \\
\hline & 3 & $4 \mathrm{Apr}$ & $22: 13$ & $57^{\circ} 40^{\prime}$ & $155^{\circ} 09^{\prime}$ & 247 & 292 \\
\hline & 4 & $5 \mathrm{Apr}$ & $04: 43$ & $57^{\circ} 41^{\prime}$ & $155^{\circ} 10^{\prime}$ & 263 & 302 \\
\hline & 5 & $12 \mathrm{Apr}$ & $01: 26$ & $57^{\circ} 38^{\prime}$ & $155^{\circ} 18^{\prime}$ & 227 & 336 \\
\hline & 6 & $12 \mathrm{Apr}$ & $02: 31$ & $57^{\circ} 39^{\prime}$ & $155^{\circ} 17^{\prime}$ & 197 & 323 \\
\hline & 7 & $12 \mathrm{Apr}$ & $12: 33$ & $57^{\circ} 38^{\prime}$ & $155^{\circ} 17^{\prime}$ & 243 & 320 \\
\hline & 8 & $12 \mathrm{Apr}$ & $13: 56$ & $57^{\circ} 39^{\prime}$ & $155^{\circ} 17^{\prime}$ & 274 & 325 \\
\hline \multirow[t]{7}{*}{1989} & 1 & $7 \mathrm{Apr}$ & $09: 03$ & $57^{\circ} 34^{\prime}$ & $155^{\circ} 18^{\prime}$ & 230 & 320 \\
\hline & 2 & $7 \mathrm{Apr}$ & $12: 38$ & $57^{\circ} 38^{\prime}$ & $155^{\circ} 14^{\prime}$ & 243 & 295 \\
\hline & 3 & $7 \mathrm{Apr}$ & $15: 43$ & $57^{\circ} 38^{\prime}$ & $155^{\circ} 16^{\prime}$ & 238 & 306 \\
\hline & 4 & $7 \mathrm{Apr}$ & $19: 38$ & $57^{\circ} 38^{\prime}$ & $155^{\circ} 13^{\prime}$ & 241 & 292 \\
\hline & 5 & $10 \mathrm{Apr}$ & $02: 17$ & $57^{\circ} 38^{\prime}$ & $155^{\circ} 16^{r}$ & 225 & 309 \\
\hline & 6 & $10 \mathrm{Apr}$ & $04: 35$ & $57^{\circ} 38^{\prime}$ & $155^{\circ} 16^{\prime}$ & 184 & 328 \\
\hline & 7 & $15 \mathrm{Apr}$ & $00: 43$ & $57^{\circ} 39^{\prime}$ & $155^{\circ} 18^{\prime}$ & 215 & 340 \\
\hline
\end{tabular}


dant pelagic predator, were preserved whole at sea and analyzed in the laboratory during the last 2 years of sampling. The entire contents of these stomachs were removed and the relative fullness of each stomach was visually assessed and assigned a rank from 0 (empty) to 5 (fully distended). The contents were identified to major taxonomic categories and weighed to the nearest $0.001 \mathrm{~g}$ only for the years 1988 and 1989 .

A daily ration $(D)$ for walleye pollock was estimated for each year $i(1986,1988$ and 1989 only) using the following model:

$$
D_{i}=F \times R \times 24
$$

which requires an estimate of gastric evacuation rate $(R)$ and the mean weight or number of prey over a $24 \mathrm{~h}$ period $(F)$ (Eggers 1977). Boisclair \& Leggett (1988) found this method yielded similar daily ration estimates to those of the more statistically rigorous Elliott \& Persson (1978) model.

Estimates of $R$ are usually determined in the laboratory. We used estimates of juvenile walleye pollock evacuation rates given by Smith et al. (1989) appropriate to the temperatures and meal sizes for our study. We have assumed that the evacuation rate for eggs is about the same as for other food types. Since evacuation rates are known to be dependent on body size, we scaled the rates for juveniles to the mean predator size in each year according to the relationship given in Smith et al. (1989).

As a check on the suitability of these evacuation rates, we attempted some preliminary experiments at sea using adult walleye pollock ( 39 to $53 \mathrm{~cm}$ ) collected in brief midwater trawls. These fish were maintained in a large covered deck tank supplied with filtered seawater at around $5^{\circ} \mathrm{C}$ for $24 \mathrm{~h}$ prior to use in the experiments. The pollock were each then force-fed a gelatin capsule containing 50 fertilized eggs and allowed to digest these for set periods of time. Previous experiments had shown that it takes 1 to $2 \mathrm{~h}$ to break down the gelatin capsules in pollock stomachs. Three fish were then sacrificed at $4,8,12,16$ and $24 \mathrm{~h}$ after feeding and the eggs remaining in the stomach were recovered.

The number of eggs consumed during each year $i$ $\left(C_{i}\right)$ was estimated by the following:

$$
C_{1}=D_{i} \times N_{i} \times I
$$

where $N_{i}=$ abundance of consumers; $I=$ incubation time in days ( $=14)$. This assumes that all the spawning takes place simultaneously and that all predators are in the area of maximum spawning throughout this $2 \mathrm{wk}$ period. Neither of these assumptions is entirely valid. However, data for 1981 indicate that the $14 \mathrm{~d}$ around the peak spawning time encompasses around 90 to 95 $\%$ of the annual egg production (Kim \& Gunderson
1989). Although some adults may move out of the main spawning area before all the eggs have hatched, this fraction is generally very small. Hence, our estimates may be considered the maximum possible consumption by the predators

The abundance of potential predators in the area of maximum egg density was determined from hydroacoustic and trawl surveys conducted on the 'Miller Freeman' 1 to 2 wk before the egg survey. Predator abundances were estimated based on hydroacoustic transect densities averaged for the $50 \mathrm{~m}$ directly above bottom within a standardized area of ca $8500 \mathrm{~km}^{2}$ (Fig. 1) during the 3 years $(1986,1988$, and 1989) for which a sufficient number of stomachs were examined. These abundances represent $76.9,77.4$, and $74.2 \%$, respectively, of the total Shelikof Strait hydroacoustic abundance estimates from the 3 years. Each transect density was weighted by the number of observations made along that transect. The total abundance was apportioned to the various year classes based on age frequency distributions available from trawl catches in the area of maximum egg density (E. Nunnalee \& N. Williamson, NMFS, Seattle, unpubl.).

In order to measure filtration rates of adult pollock, fish were collected in midwater hauls and individually placed in $300 \mathrm{l}$ polyethylene enclosures filled with filtered seawater and containing a known concentration (1 per liter) of buoyant eggs. These enclosures were then suspended in the deck tank aboard the research vessel and covered with dark plastic. The fish were then removed at predetermined time intervals $(<1 \mathrm{~h})$ and their stomachs excised and examined for eggs.

\section{RESULTS}

\section{Occurrence of eggs in stomachs}

Eggs were found in at least some pollock stomachs collected from each of the 24 hauls made (Table 2). With the exception of most of the collections made during 1989, pollock eggs were found in at least half the stomachs containing food in each haul. Egg numbers varied greatly among hauls but generally showed a decrease in maximum and mean eggs consumed in the last 2 years (Table 2).

Only 1 of the 69 eulachon (length range 102 to 240 $\mathrm{mm}$ ) examined from 7 hauls in 1988 and none of the 65 eulachon examined from 6 hauls made during 1989 (97 to $229 \mathrm{~mm}$ ) contained eggs. Since eulachon were in spawning condition when collected and their stomachs contained only trace amounts of food, we will assume that any egg consumption by eulachon at this time of year was insignificant and restrict all further data analyses to pollock. 
Table 2. Theragra chalcogramma. Stomachs examined and incidence of cannibalism upon eggs by walleye pollock by year. (nc: data not collected)

\begin{tabular}{|c|c|c|c|c|c|c|c|}
\hline Year & Haul & $\begin{array}{l}\text { No. of } \\
\text { stomachs }\end{array}$ & $\begin{array}{c}\text { Length } \\
\text { range } \\
\text { (cm) }\end{array}$ & $\begin{array}{l}\text { No. } \\
\text { with } \\
\text { food }\end{array}$ & $\begin{array}{l}\text { No. } \\
\text { with } \\
\text { eggs }\end{array}$ & $\begin{array}{l}\text { Mean } \\
\text { no. } \\
\text { eggs }\end{array}$ & $\begin{array}{c}\text { Max. } \\
\text { no. } \\
\text { eggs }\end{array}$ \\
\hline 1985 & 1 & 46 & $41-53$ & 44 & 44 & 46.71 & 242 \\
\hline \multirow[t]{6}{*}{1986} & 1 & 103 & $22-57$ & $\mathrm{nc}$ & 46 & 1.33 & 22 \\
\hline & 2 & 103 & $11-55$ & $\mathrm{nc}$ & 71 & 4.71 & 27 \\
\hline & 3 & 97 & $19-52$ & $\mathrm{nc}$ & 63 & 2.94 & 41 \\
\hline & 4 & 98 & $33-59$ & $\mathrm{nc}$ & 95 & 26.96 & 249 \\
\hline & 5 & 70 & $21-58$ & nc & 47 & 5.03 & 31 \\
\hline & 6 & 99 & $34-56$ & ne & 95 & 24.12 & 248 \\
\hline \multirow[t]{2}{*}{1987} & 1 & 99 & $19-64$ & 53 & 31 & 0.71 & 10 \\
\hline & 2 & 96 & $29-63$ & 74 & 60 & 2.89 & 22 \\
\hline \multirow[t]{8}{*}{1988} & 1 & 29 & $27-53$ & 24 & 16 & 4.41 & 31 \\
\hline & 2 & 25 & $21-53$ & 18 & 9 & 0.96 & 9 \\
\hline & 3 & 30 & $20-49$ & 17 & 14 & 1.50 & 7 \\
\hline & 4 & 17 & $32-62$ & 11 & 11 & 2.06 & 15 \\
\hline & 5 & 20 & $21-50$ & 16 & 14 & 4.20 & 20 \\
\hline & 6 & 7 & $11-36$ & 5 & 5 & 3.14 & 11 \\
\hline & 7 & 22 & $12-44$ & 17 & 13 & 5.09 & 24 \\
\hline & 8 & 20 & $11-60$ & 15 & 9 & 3.75 & 31 \\
\hline \multirow[t]{7}{*}{1989} & 1 & 35 & $10-50$ & 34 & 11 & 2.06 & 31 \\
\hline & 2 & 35 & $10-52$ & 32 & 14 & 1.23 & 8 \\
\hline & 3 & 35 & $21-56$ & 31 & 10 & 0.77 & 5 \\
\hline & 4 & 27 & $11-51$ & 25 & 5 & 0.22 & 2 \\
\hline & 5 & 34 & $11-61$ & 24 & 10 & 4.06 & 91 \\
\hline & 6 & 45 & $11-68$ & 36 & 11 & 1.07 & 10 \\
\hline & 7 & 25 & $35-60$ & 21 & 21 & 13.52 & 64 \\
\hline
\end{tabular}

Eggs from 21 walleye pollock stomachs collected during 1985 were assigned to early ( 1 to $5 \mathrm{~d}$ old), middle (6 to $7 \mathrm{~d}$ old) and late ( 8 to $14 \mathrm{~d}$ old) stages of development. In the sample of 981 eggs, $85.5,3.2$, and $7.5 \%$ were determined to be early, middle, and late stages, respectively. Of the remaining eggs, $1.4 \%$ were unfertilized and $2.3 \%$ were too digested to be reliably staged.

\section{Proportion of diet consisting of eggs}

Walleye pollock consumed a variety of foods during the 2 years in which detailed stomach analysis was done. Pollock eggs were the dominant food by number during 1988, comprising almost two-thirds $(64.3 \%)$ of the total number of prey items consumed (Fig. 2). By weight, however, eggs were the fourth most important prey comprising about $5 \%$ of the total food weight. The percentage of eggs in the total food consumed ranged from 57 to $78 \%$ and 1 to $16 \%$ by number and weight, respectively, in the individual hauls. The most important prey overall by weight were decapods, resulting mainly from the occurrence of several large pandalid shrimp (Pandalus spp.) in the stomachs from one station. Euphausiids (mostly Thysanoessa spp.) were the second most important food by both weight and number during 1988 (Fig. 2).

Small prey dominated the diet numerically during 1989, with copepods, poliock eggs, and Iarvaceans

\section{Pollock food 1988}

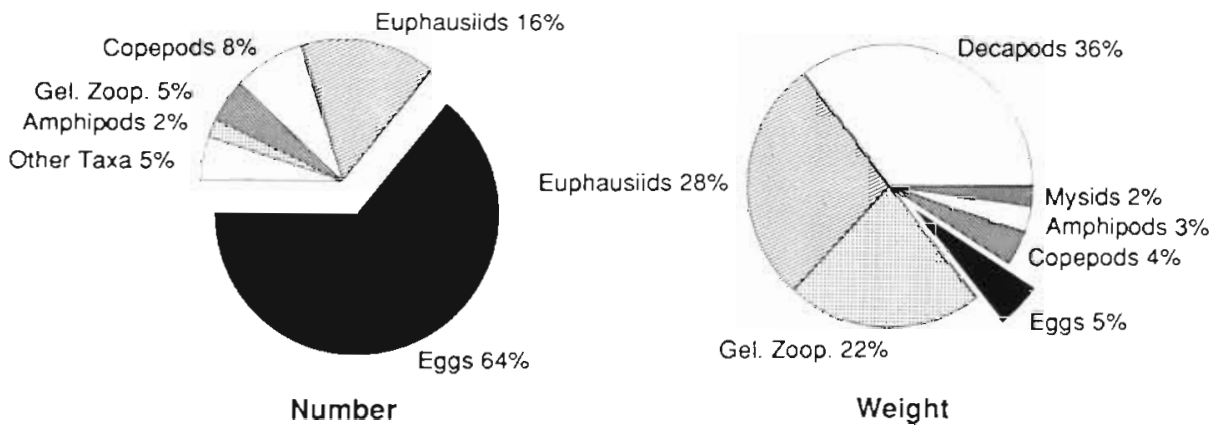

Fig. 2. Theragra chalcogramma Percent by number and weight of the major food categories found in the stomachs of walleye pollock in Shelikof Strait in 1988. The portion of the diet made up of pollock eggs is isolated for emphasis. (Gel. Zoop. = gelatinous zooplankton] 
Fig. 3. Theragra chalcogramma. Percent by number and weight of the major food categories found in the stomachs of walleye pollock in Shelikof Strait in 1989. The portion of the diet made up of pollock eggs is isolated for emphasis. (Gel. Zoop. = gelatinous zooplankton)

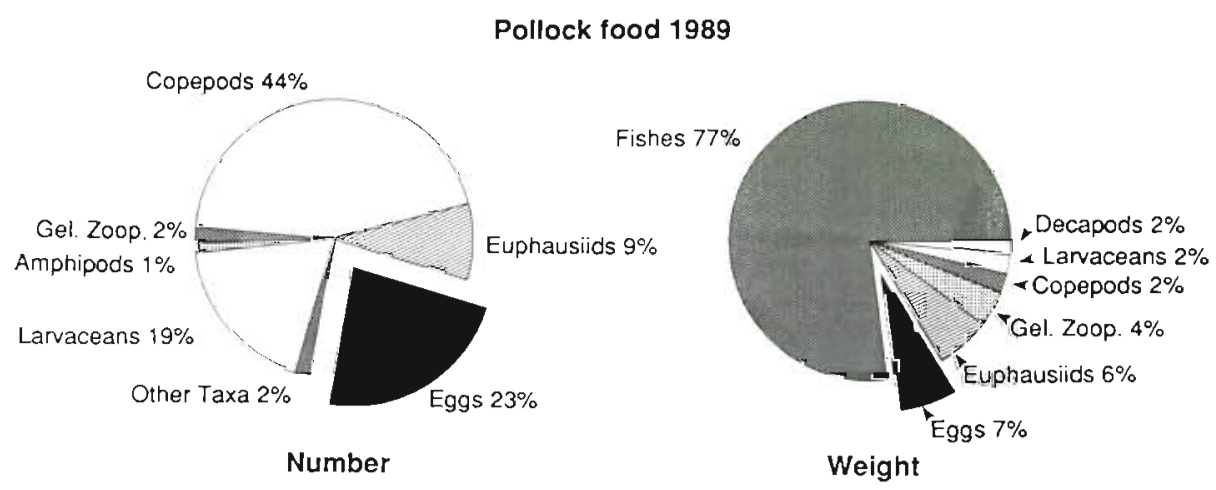

Number accounting for $86.3 \%$ of the total food consumed (Fig. 3 ). Because of the preponderance of copepods in some stomachs, eggs were relatively less important numerically but were actually of greater importance in terms of biomass compared with the 1988 results. Fish were the dominant prey by weight during 1989 and consisted almost entirely ( $>99 \%$ ) of age-1 juvenile pollock (length range 9 to $12 \mathrm{~cm}$ ) found in adult pollock collected in hauls 4 and 6 .

\section{Diel consumption of food}

Collections were grouped into $4 \mathrm{~h}$ time intervals in order to examine diel trends in feeding. Mean stomach fullness, as expressed by both percent body weight and fullness code, exhibited significant diel variations (Kruskal-Wallis Test, $p<0.001$ ) peaking during the early morning (06:00 to 10:00 h) and declining throughout the remainder of the day (Fig. 4). Both the mean number of eggs per stomach and the percentage of stomachs containing eggs were similar for most time periods (Fig. 4) but showed a substantial increase during the night (22:00 to 02:00 h). These increases are attributed mainly to the large numbers of fresh eggs in pollock stomachs collected during 1989 in haul 7 (Table 2).

\section{Dietary variations by age and maturity}

The size distribution of fish analyzed during 1988 and 1989 shows several distinct modes corresponding to the different pollock age groups present in the strait (Fig. 5). The first 2 modes, centered around 120 and 220 $\mathrm{mm}$, represented 1 and 2 year-olds; these immature fish were examined separately from the age- $3+$ pollock in spawning condition. Although stomach fullness, expressed by both percent body weight and fullness code, was much higher in the age-1 fish than in either of the other groups, these fish consumed a similar mean number of eggs as the age-2 fish, and significantly

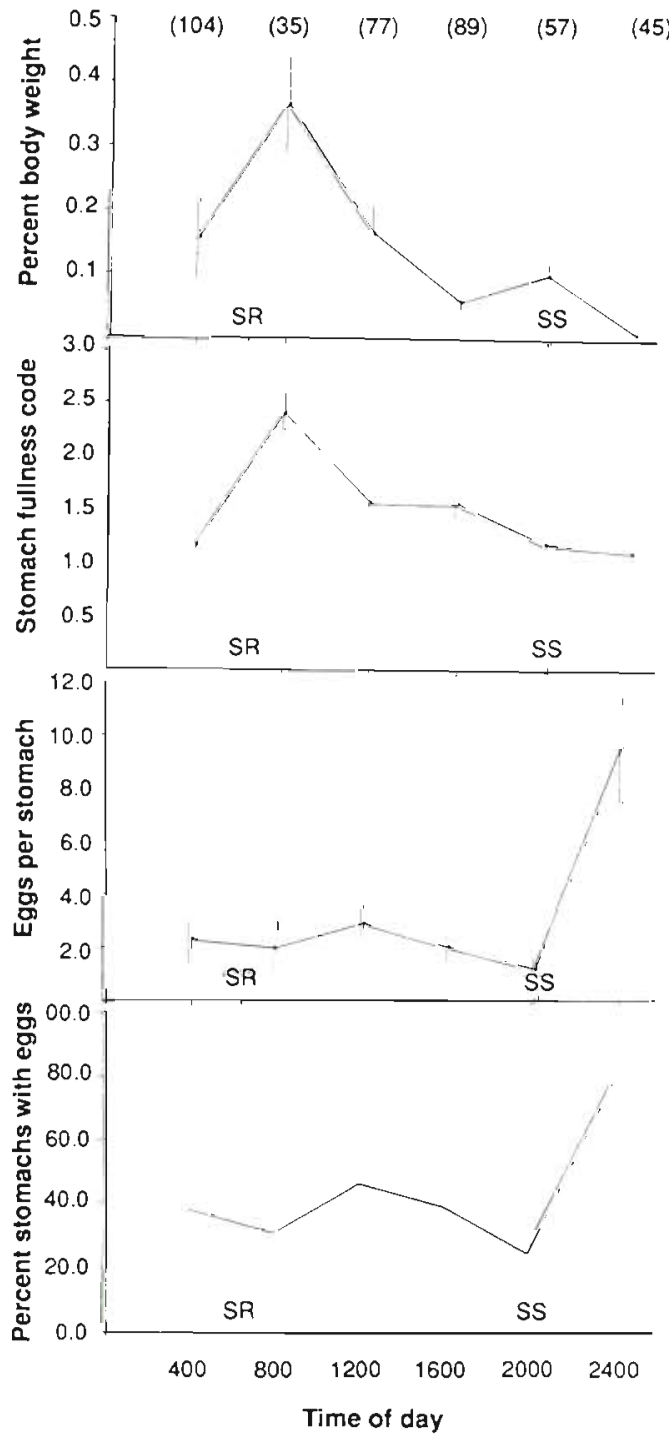

Fig. 4. Theragra chalcogramma. Percent of total body weight made up by stomach contents, stomach fullness code, mean number of eggs per stomach and percentage of stomachs containing eggs by $4 \mathrm{~h}$ time periods for 1988 and 1989. The number of stomachs examined during each period is shown in parentheses in the upper figure. Data are means \pm 1 SE. Approximate times of sunrise (SR) and sunset (SS) are indicated 
(Mann-Whitney Test, $\mathrm{p}<0.001$ ) fewer mean eggs than the age- $3+$ fish (Table 3 ). Walleye pollock eggs were found in only 5 of the $62(8.1 \%)$ age- 1 fish and 3 of 22 $(13.6 \%)$ age- 2 fish examined compared with 165 of 323 $(51.1 \%)$ of the age-3+ fish. Since the majority of the stomachs we examined from both years were age- 3 and older, the proportions of walleye pollock eggs by both weight and number within this group increased only slightly $(<1 \%$ in all cases) from those shown in Figs. 2 \& 3.

Overall food consumption and number of eggs per stomach were analyzed by stage of maturity for the walleye pollock stomachs collected during 1989, the only year for which maturity data were available (Table 4). There were significant differences in the mean stomach fullness, expressed as a percent of total body weight, and the number of eggs per stomach (KruskalWallis Test, $\mathrm{p}<0.001$ for both) among the 4 maturity groups. The highest egg consumption and lowest stomach fullness were found for the actively spawning individuals, whereas the lowest egg consumption and highest stomach fullness were found for immature and developing fish (Table 4).

\section{Relation to abundance in the plankton}

The mean number of eggs found in the stomachs for each haul was positively related to egg density throughout the water column determined from plankton collections at the nearest grid station. The relation between these 2 variables was best described by a log$\log$ function (Fig. 6). The $95 \%$ confidence interval of the regression coefficient was 0.308 to 1.986. This range included a slope of 1.0 and therefore suggests that these eggs were consumed in proportion to their abundance in the plankton.

\section{Egg evacuation experiments}

Although there was some variation among individual fish, the number of eggs left in the stomach remained high for the $8 \mathrm{~h}$ immediately after feeding but then declined rapidly after that time (Fig. 7). After $24 \mathrm{~h}$, there were few eggs left in the stomachs and 1 of the 3 stomachs contained no eggs at all.

\section{Egg consumption estimates}

Using yearly mean abundance of eggs found in the stomachs and size-adjusted evacuation rates, we estimated the number of eggs consumed per day for age classes combined and for fish ages 3 and older (Table 5). These estimates show a substantially higher consumption for 1986 than for either 1988 or 1989. The estimate of total egg consumption by the entire population, as estimated from hydroacoustic surveys in 1986, was only about twice that of 1988, the next highest year (Table 5).

Given the uncertainties in the estimates we used for evacuation rates and adult population abundances, we calculated egg consumption rates using alternative values for these 2 parameters to estimate maximum potential consumption. We first assumed that the evacuation rates could be twice those used in Table 5 . We also used the total spawning biomass in the western Gulf of Alaska determined from cohort analysis (Hollowed \& Megrey in press) as well as the more localized abundance determined by hydroacoustic estimates. Although most of the walleye pollock in the western Gulf of Alaska spawn in Shelikof Strait, the cohort analysis may include a small percentage of pollock which spawn elsewhere; therefore, these abundances are probably overestimates and were used to reflect the maximum possible predator abundance. Egg consumption estimates based on combinations of these 2 digestion rates and adult abundances were compared with annual estimates of egg production (Hollowed \& Megrey 1990 ) based on age-specific maturity rates, fecundity, and abundance estimates for the 3 years. Using the most liberal estimates for both the evacuation rates and adult walleye pollock population estimates, pollock consumption ranged from 0.10 to $0.22 \%$ of the total egg production for the 3 years (Table 6)

Table 3. Theragra chalcogramma. Trends in food and egg consumption with increasing size of walleye pollock collected in Shelikof Strait during 1988 and 1989. Numbers in parentheses: standard errors of the mean

\begin{tabular}{|c|c|c|c|c|c|c|}
\hline $\begin{array}{l}\text { Age } \\
\text { group }\end{array}$ & $\begin{array}{l}\text { Length } \\
\text { range } \\
\text { (mm) }\end{array}$ & $\begin{array}{c}\text { No. } \\
\text { of fish } \\
\text { sampled }\end{array}$ & $\begin{array}{l}\text { Mean } \\
\text { percent } \\
\text { body wt }\end{array}$ & $\begin{array}{l}\text { Mean } \\
\text { fullness } \\
\text { code }\end{array}$ & $\begin{array}{c}\text { Mean } \\
\text { no. eggs } \\
\text { stomach }\end{array}$ & $\begin{array}{c}\text { Percent } \\
\text { occurrence } \\
\text { of eggs }\end{array}$ \\
\hline 1 & $100-140$ & 62 & $\begin{array}{c}0.40 \\
(0.07)\end{array}$ & $\begin{array}{c}2.14 \\
(0.18)\end{array}$ & $\begin{array}{c}0.226 \\
(0.127)\end{array}$ & 8.1 \\
\hline 2 & $183-250$ & 22 & $\begin{array}{c}0.08 \\
(0.04)\end{array}$ & $\begin{array}{c}1.45 \\
(0.31)\end{array}$ & $\begin{array}{c}0.227 \\
(0.146)\end{array}$ & 13.6 \\
\hline $3+$ & $267-679$ & 323 & $\begin{array}{c}0.08 \\
(0.02)\end{array}$ & $\begin{array}{c}1.28 \\
(0.06)\end{array}$ & $\begin{array}{c}3.650 \\
(0491)\end{array}$ & 51.1 \\
\hline
\end{tabular}


Fig. 5. Theragra chalcogramma. Length distributions of pollock examined from 1988 and 1989 stomach sampling

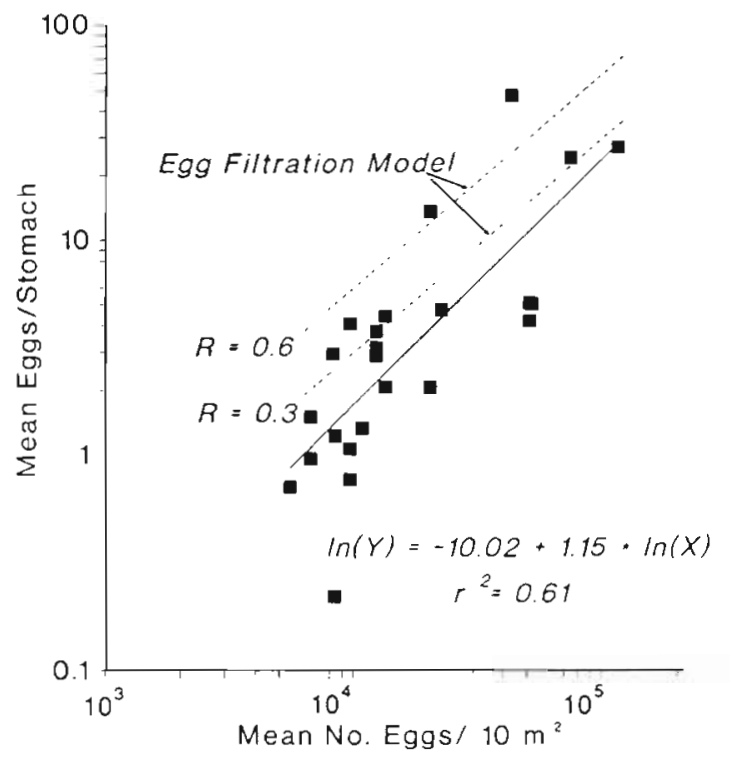

Fig. 6. Theragra chalcogramma. Relationship between mean number of eggs in the stomachs and egg density in the plankton at the nearest tow location for all years. Solid line and the equation is the regression line fit to the data. Dashed lines delimit the range of eggs per stomach predicted by the egg filtration model between fast and slow gastric evacuation

$$
\text { rates }
$$
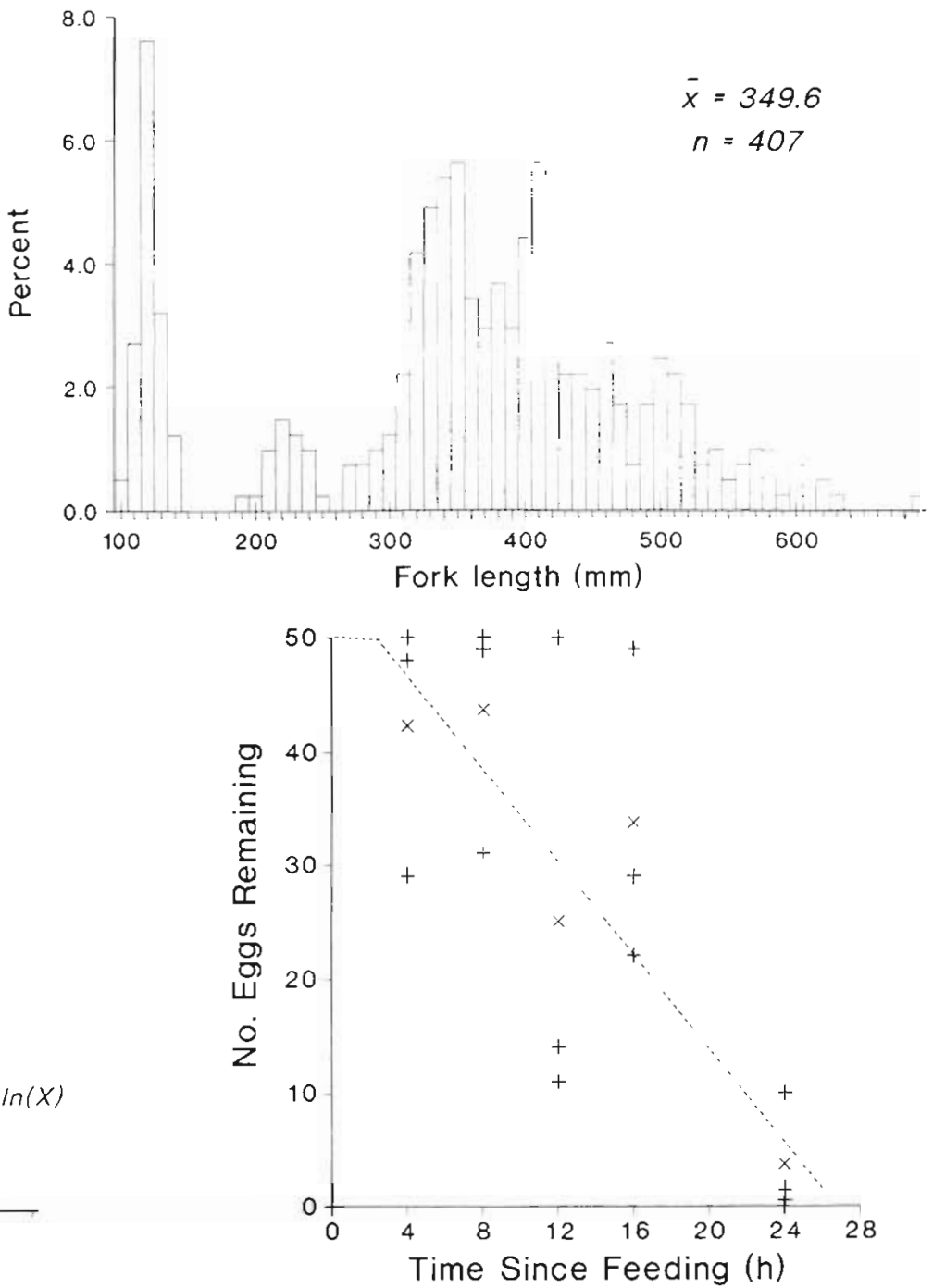

Fig. 7. Theragra chalcogramma. Egg numbers remaining in the stomachs at the time intervals shown from shipboard experiments conducted at $5^{\circ} \mathrm{C} .(+)$ Actual number of eggs recovered at each time interval; $(x)$ mean of the 3 observations. Dashed line was fit to the mean values and includes a lag period of $2 \mathrm{~h}$ to account for digestion of the gelatin capsules (see text)

Table 4. Theragra chalcogramma. Trends in overall food consumption and egg consumption with maturity stage of walleye pollock collected in Shelikof Strait during 1989. Numbers in parentheses: standard errors of the mean

\begin{tabular}{|c|c|c|c|c|}
\hline $\begin{array}{l}\text { Maturity } \\
\text { stage }\end{array}$ & $\begin{array}{c}\text { No. } \\
\text { of fish } \\
\text { sampled }\end{array}$ & $\begin{array}{c}\text { Mean } \\
\text { percent } \\
\text { body wt }\end{array}$ & $\begin{array}{c}\text { Mean } \\
\text { no. eggs } \\
\text { stomach }^{-1}\end{array}$ & $\begin{array}{l}\text { Percent } \\
\text { occurrence } \\
\text { of eggs }\end{array}$ \\
\hline Immature and developing & 99 & $\begin{array}{c}0.37 \\
(0.07)\end{array}$ & $\begin{array}{c}0.360 \\
(0.011)\end{array}$ & 14.0 \\
\hline Mature & 20 & $\begin{array}{c}0.06 \\
(0.05)\end{array}$ & $\begin{array}{c}1.600 \\
(0.907)\end{array}$ & 35.0 \\
\hline Spawning & 65 & $\begin{array}{c}0.02 \\
(0.01)\end{array}$ & $\begin{array}{c}6.062 \\
(1.733)\end{array}$ & 58.5 \\
\hline Spent & 52 & $\begin{array}{c}0.10 \\
(0.04)\end{array}$ & $\begin{array}{c}4.038 \\
(1.527)\end{array}$ & 42.3 \\
\hline
\end{tabular}


Table 5. Theragra chalcogramma. Mean egg abundances, daily egg consumption per fish, and total annual consumption for all pollock and age- 3 and older pollock in the main spawning area in Shelikof Strait

\begin{tabular}{|ccccccc|}
\hline Year & $\begin{array}{c}\text { Mean no. eggs } \\
\text { stomach }^{-1}\end{array}$ & $\begin{array}{c}\text { Mean fish } \\
\text { weight }(\mathrm{g})\end{array}$ & $\begin{array}{c}\text { Evac. rate } \\
\mathrm{h}^{-1}\end{array}$ & $\begin{array}{c}\text { Eggs consumed } \\
\mathrm{d}^{-1}\end{array}$ & $\begin{array}{c}\text { Adult } \\
\text { abundance }\end{array}$ \\
\hline All ages & & & & & & $\begin{array}{c}\text { Total egg } \\
\text { consumption }\end{array}$ \\
1986 & 15.53 & 477.7 & 0.0316 & 11.78 & $3.04 \times 10^{8}$ & $5.01 \times 10^{10}$ \\
1988 & 3.11 & 246.5 & 0.0431 & 3.22 & $4.58 \times 10^{8}$ & $2.06 \times 10^{10}$ \\
1989 & 2.85 & 382.8 & 0.0356 & 2.44 & $1.55 \times 10^{8}$ & $5.27 \times 10^{9}$ \\
Age 3+ & & & & & & \\
1986 & 19.48 & 770.9 & 0.0203 & 9.49 & $1.63 \times 10^{8}$ & $2.16 \times 10^{10}$ \\
1988 & 3.42 & 283.2 & 0.0375 & 3.08 & $3.83 \times 10^{8}$ & $1.65 \times 10^{10}$ \\
1989 & 3.87 & 523.9 & 0.0284 & 2.64 & $1.10 \times 10^{8}$ & $4.07 \times 10^{9}$ \\
\hline
\end{tabular}

\section{Egg filtering model}

Because pollock are not actively feeding during the spawning season and not likely to see eggs at depths of 200 to $300 \mathrm{~m}$, it seems plausible that eggs are passively ingested by retention on the gill rakers during ventilation. A simple passive filtration model was constructed to compare predictions of egg consumption against field data. The model used is as follows:

$$
E=V \times R \times B \times D
$$

where $E=$ egg consumption (number consumed $\mathrm{d}^{-1}$ ); $V=$ ventilation volume $\left(\mathrm{l} \mathrm{d}^{-1} \mathrm{~kg}^{-1}\right)$ which is a function of $\mathrm{O}_{2}$ consumption rate and $\mathrm{O}_{2}$ utilization; $R=$ retention efficiency, here assumed to be $100 \% ; B=$ fish biomass $(\mathrm{kg})$; and $D=$ egg density (no. $\mathrm{l}^{-1}$ ). $B$ and $D$ are data inputs, and $V$ was approximated (lacking data on walleye pollock) from the relationship between respiration rate and ventilation volume of trout with $10 \%$ oxygen utilization at $5^{\circ} \mathrm{C}$ (from Shelton 1970). The respiration rate of walleye pollock at $5.5^{\circ} \mathrm{C}$ is from Smith et al. (1988):

$$
Y=1.55 X+19.84
$$

where $Y=$ oxygen consumption $\left(\mu l g^{-1} \mathrm{~h}^{-1}\right)$; and $\mathrm{X}=$ temperature $\left(5.5^{\circ} \mathrm{C}\right)$. The ventilation volume thus calculated was $0.864 \mathrm{~m}^{3} \mathrm{~d}^{-1} \mathrm{~kg}^{-1}$.
The number of eggs filtered per hour in the lab experiments was highly variable (range 2 to 88 ) averaging $17.3 \mathrm{eggs}^{-1}$. Using our model, we predict that our experimental fish at an average weight of $0.65 \mathrm{~kg}$ would filter around $23 \mathrm{l} \mathrm{h}^{-1}$ and, at a density of 1 egg $l^{-1}$ used in the experiments, consume 23 eggs $\mathrm{h}^{-1}$.

Daily egg consumption was calculated from the filtration model for the range of egg densities observed (assuming eggs are all in the bottom $100 \mathrm{~m}$ ). The mean number of eggs per stomach was calculated from Eq. (1) by solving for $F$ with $R$ at 0.03 and 0.06 , which represented slow and fast evacuation rates, respectively. The mean fish size used was $0.5 \mathrm{~kg}$ (from Table 5). Predicted numbers of eggs per stomach fit observed data fairly well, especially at high egg abundances (Fig. 6). The model tended to overestimate eggs per stomach at low egg densities.

\section{DISCUSSION}

There are several sources of bias associated with our egg consumption calculations which may impact our results. As in any study that utilizes trawl-caught fishes, a potential for feeding in nets during capture exists in our study. Eggs consumed in the codend could

Table 6. Theragra chalcogramma. Estimated yearly egg consumption rates for adult pollock (age 3+) from Shelikof Strait calculated using combinations of 2 different evacuation rates and abundances levels for the 3 years. See text for derivation of the different models. Percent consumed is given in parentheses below each value

\begin{tabular}{|cccccc|}
\hline Year & $\begin{array}{c}\text { Total egg } \\
\text { production }\end{array}$ & $\begin{array}{c}\text { Low abundance } \\
\text { Slow evacuation }\end{array}$ & $\begin{array}{c}\text { Low abundance } \\
\text { Fast evacuation }\end{array}$ & $\begin{array}{c}\text { High abundance } \\
\text { Slow evacuation }\end{array}$ & $\begin{array}{c}\text { High abundance } \\
\text { Fast evacuation }\end{array}$ \\
\hline 1986 & $2.113 \times 10^{14}$ & $2.163 \times 10^{10}$ & $4.326 \times 10^{10}$ & $2.345 \times 10^{11}$ & $4.690 \times 10^{11}$ \\
& & $(0.010)$ & $(0.020)$ & $(0.111)$ & $(0.222)$ \\
1988 & $1.074 \times 10^{14}$ & $1.650 \times 10^{10}$ & $3.301 \times 10^{10}$ & $9.041 \times 10^{10}$ & $1.808 \times 10^{11}$ \\
1989 & $1.010 \times 10^{14}$ & $(0.015)$ & $(0.031)$ & $(0.084)$ & $(0.168)$ \\
& & $(0.004)$ & $\left(0.149 \times 10^{9}\right.$ & $5.085 \times 10^{10}$ & $1.017 \times 10^{11}$ \\
& & & $(0.008)$ & $(0.050)$ & $(0.101)$ \\
\hline
\end{tabular}


originate from either previously spawned eggs floating in the plankton or from eggs extruded from ripe females as they are compressed in the net. We believe that the first method of post-capture ingestion is unlikely since the codend mesh size was large enough $(1 \mathrm{~cm})$ to allow particles much larger than pollock eggs to pass through. Although some contamination from the second situation is possible, most of the eggs found in the stomachs were fertilized and many were at advanced stages of development (as exemplified by the 1985 eggs we staged) and well digested.

Another source of error may be the assumption that evacuation rates for eggs ingested in the field are similar to those found by Smith et al. (1989) for juvenile pollock feeding on shrimp in the laboratory at similar temperatures. Although we were not able to find any studies which compared the evacuation rates of fish eggs to those of other prey under the same conditions, the few laboratory and field studies available on egg clearance times suggest that these are relatively short, generally less than $24 \mathrm{~h}$ (Hunter \& Kimbrell 1980, Daan et al. 1985). To account for potential error in evacuation rates, we used a range of values (ca 17 to $34 \mathrm{~h}$ ) in our calculations which bracketed $24 \mathrm{~h}$. Our preliminary field experiments using adult pollock force-fed gelatin capsules containing a known number of eggs showed almost complete evacuation in about $24 \mathrm{~h}$ at $5{ }^{\circ} \mathrm{C}$. This time to complete evacuation of eggs may be high because of the use of the capsules and the potential stress to the fish caused by force-feeding. Thus the field experiments demonstrated that the range of evacuation rates we used was probably realistic. Based on our field data, walleye pollock show a distinct diel periodicity in feeding such that stomach fullness is at a maximum during the early morning and then declines at a rate sufficient to empty the stomach by the next feeding cycle.

The lower cannibalism rates in the younger age groups (ages 1 and 2) may be related to their vertical distribution in the water column. Pollock in Shelikof Strait show vertical stratification by age groups with a substantial increase in mean age with depth (Muigwa 1989, E. Nunnallee, NMFS, Seattle, unpubl.); the majority of the adult spawners are found in the deepest layers. The younger age classes were relatively rare in our predator haul collections, and we suspect that they were captured mainly at shallower depths during the descent and ascent phases of the hauls. Kendall \& Kim (1989) found the highest egg densities in the lowest layers during the 1985 spawning season with over $70 \%$ of the eggs found at depths $>218 \mathrm{~m}$ and only $2.5 \%$ of the total egg abundance found at depths shallower than $157 \mathrm{~m}$. These authors also found a good correlation between the density of eggs in depth-stratified plankton tows and the number of eggs in pollock stomachs sampled from trawl hauls in the same layers. Significantly higher egg abundances were found in stomachs collected from the deeper layers. Thus we feel that our abundance estimates calculated from only the lower layer spawning concentrations (47.3\% of the entire water column abundance in 1988) better approximate the actual population consuming pollock eggs than those calculated from all layers.

Eggs preyed upon by adults were primarily those in the early stages of development. This corresponds to the known vertical distribution of eggs, with the younger stages located deeper, overlapping the habitat of mature adults (Kendall \& Kim 1989). Following hatching, the larvae rise in the water column and are generally distributed in the upper $60 \mathrm{~m}$ of the water column (Kendall et al. 1987). Residence at this depth during the vulnerable yolk-sac or early larval period may provide larvae with a refuge from fish predators residing at greater depths below the thermocline. Based on hydroacoustic and survey data, abundances of fishes in the surface layers during the late spring months are generally low in Shelikof Strait. Examination of a limited number $(n=29$ ) of juvenile and adult pollock stomachs collected from 3 hauls taken in the upper $100 \mathrm{~m}$ during the late larval period (24 May to 1 June 1988) revealed no evidence of cannibalism on pollock larvae (Brodeur unpubl.). Eulachon, the only other abundant pelagic fish found in Shelikof Strait, also reside near the bottom in spring (Williamson in press).

We believe that the cannibalism we observed on eggs is not the result of active selection of eggs over other potential prey, but rather a passive ingestion during normal gill ventilation. Several lines of evidence support this conclusion. Pollock eggs are generally smaller than most of the normal prey items of adult pollock such as adult copepods, euphausiids, and fishes (Dwyer et al. 1987), and the overall biomass of these evasive prey may be several orders of magnitude greater than that of pollock eggs. Pollock eggs were often the only items found in the stomachs in actively spawning individuals during the spawning season, at a time when feeding motivation appears to be at its lowest level during the year (Dwyer et al. 1987). We found that actively spawning fish had little food in their stomachs overall compared with non-spawning fish yet they consumed a substantial number of eggs. Also, light levels at the depths where most of the cannibalism occurs are probably insufficient for pollock to visually cue on eggs. Finally, predicted results from a passive filtration model fit observed data surprisingly well, considering the crude approximations of adult behavior, physiology, and vertical distributions used in the model. An explanation for the filtration model tending to overestimate egg consumption at low egg densities might be 
that the eggs are older and more vertically dispersed at low densities (Kim 1987).

Although the egg production estimates are also subject to some sampling error, they are of the same order of magnitude as independent estimates based on field data $\left(5.0 \times 10^{14}\right.$ for 1986 ; Bates 1990). Both estimates of egg abundance indicate that the number of eggs produced is several orders of magnitude above the estimated number consumed. Despite the low consumption rates we found during the later years of our study, the high numbers of eggs found in the stomachs during some years could have affected recruitment dynamics during years of peak walleye pollock abundance. The empirical relationship between egg density in the plankton and consumption by pollock was linear, suggesting a density-independent functional response. This is in contrast to the situation suggested for filterfeeding anchovy off California and South Africa where egg consumption rates increased at higher egg densities (Hunter \& Kimbrell 1980, Valdés et al. 1987). The few data points we have at the higher egg densities, however, lie along or above the predicted regression equation (Fig. 6), suggesting that this reldtionship could be nonlinear at high densities. Therefore, the annual losses due to cannibalism could have been significant during the early 1980 s when walleye pollock population sizes and egg densities were extremely high relative to the years we examined.

Although stomach content data is not available from this period, we attempted to examine the magnitude of predation at these high stock levels based on the data on hand. If we extrapolate our egg density to eggs per stomach relationship [ln(eggs per stomach) $=-10.02 \times$ $1.15 \ln$ (egg density) ] beyond our existing data up to the mean egg density found in the egg patch during 1981 (221 571 eggs $10 \mathrm{~m}^{-2}$; Incze et al. 1989) and use evacuation rates adjusted for the estimated mean weight $(516.9 \mathrm{~g})$ of age- 3 and older fish from the hydroacoustic cruises that year (Kim \& Gunderson 1989), we arrive at a mean of 60.1 eggs per stomach and a daily consumption of from 41.5 to 83.1 eggs per fish (Table 7). These estimates are higher than the mean estimates for the years for which we do have data, but these mean numbers of eggs per stomach are substantially less than the highest number of eggs per stomach recorded in our analysis (Table 2); hence, we feel that it is not an unrealistic number. Adult abundances (for fish age 3 and older) and egg production estimates were calculated as before from cohort analysis (Hollowed \& Megrey in press) and from the 1981 hydroacoustic surveys (Kim \& Gunderson 1989). Our estimates of the egg consumption by walleye pollock during 1981 lie between 0.6 and $2.1 \%$ of the total egg production (Table 7).

This estimate is supported by applying the filtration model to the 1981 egg abundance data. In 1981, the average number of eggs per $\mathrm{m}^{3}$ was 223 ; therefore, the average fish would be expected to passively filter 112.4 eggs $\mathrm{d}^{-1}$, assuming a retention efficiency factor of 1.0 . An adult fish biomass of $3.8 \times 10^{9} \mathrm{~kg}$ in 1981 would filter $3.29 \times 10^{9} \mathrm{~m}^{3} \mathrm{~d}^{-1}$. Estimating that eggs inhabit a volume of $11.4 \times 10^{11} \mathrm{~m}^{3}$, adults would filter $0.29 \%$ of available water per day. Therefore egg loss would be $4 \%$ over the $14 \mathrm{~d}$ incubation period. This value lies above our field estimates at slow and fast evacuation rates (Table 7 ), but the assumption of $100 \%$ retention efficiency of eggs by adult pollock may not be realistic.

In summary, we conclude that cannibalism is unlikely to be a major source of the high egg mortality seen in 1981; the remaining losses must be attributable either to transport out of the sampling area or to consumption by invertebrate predators or smaller pelagic fishes (e.g. Pacific sand lance Ammodytes hexapterus) unavailable to our trawls. As a consequence of relatively low egg mortality due to cannibalism even in a high adult stock biomass year, we further conclude that pollock egg cannibalism is unlikely to be a major factor in density-dependent stock recruit relationships in this population.

Extensive predation by adult pollock on juveniles has previously been documented for the Bering Sea walleye pollock population (Dwyer et al. 1987, Bailey 1989,

Table 7. Theragia chalcogramma. Estimated egg consumption and production tor 1981 based on slow and fast evacuation rates and abundance and egg production rates from cohort analysis (Megrey unpubl.) and hydroacoustic estimates (Kim \& Gunderson 1989)

\begin{tabular}{|lcccccccc}
\hline Evac. $\begin{array}{c}\text { Mean eggs } \\
\text { stomach }\end{array}$ & $\begin{array}{c}\text { Mean fish } \\
\text { weight (g) }\end{array}$ & $\begin{array}{c}\text { Evacuation } \\
\text { rate }^{-1}\end{array}$ & $\begin{array}{c}\text { Eggs } \\
\text { consumed d }\end{array}$ & $\begin{array}{c}\text { Adult } \\
\text { abundance }\end{array}$ & $\begin{array}{c}\text { Total egg } \\
\text { consumption }\end{array}$ & $\begin{array}{c}\text { Total egg } \\
\text { production }\end{array}$ & $\begin{array}{c}\text { Percent } \\
\text { consumed }\end{array}$ \\
\hline Cohort analysis & & & & & & & \\
Slow & 60.10 & 516.9 & 0.0288 & 41.54 & $7.38 \times 10^{9}$ & $4.29 \times 10^{12}$ & $4.02 \times 10^{14}$ & 1.066 \\
Fast & 60.10 & 516.9 & 0.0576 & 83.08 & $7.38 \times 10^{9}$ & $8.58 \times 10^{12}$ & $4.02 \times 10^{14}$ & 2.133 \\
Hydroacoustic surveys & & & & & & & \\
Slow & 60.10 & 516.9 & 0.0288 & 41.54 & $7.88 \times 10^{9}$ & $4.58 \times 10^{12}$ & $7.17 \times 10^{14}$ & 0.639 \\
Fast & 60.10 & 516.9 & 0.0576 & 83.08 & $7.88 \times 10^{9}$ & $9.17 \times 10^{12}$ & $7.17 \times 10^{14}$ & 1.279 \\
\hline
\end{tabular}


Livingston 1989), but the relationship between the magnitude of cannibalism and subsequent recruitment of the year class is unclear (Francis \& Bailey 1983, Bailey et al. 1986). Cannibalism on juveniles has not been documented in the limited feeding studies conducted to date on the pollock population of the Western Gulf of Alaska (Megrey 1989a). However, the high consumption of 1-yr-old pollock by the older age groups we observed during 1989 merits further study as a possible density dependent mechanism operating in this population.

Acknowledgements. We greatly appreciate the assistance provided in the collection of samples at sea by personnel at the Alaska Fisheries Science Center and in particular, Mary Yoklavich and Ann Matarese. We thank A. W. Kendall, D. R. Gunderson, B. A. Megrey, and A. B. Hollowed for comments on the manuscript and E. P. Nunnallee and N. Williamson for allowing us the use of their unpublished data. This work is part of the NOAA Fishery Oceanography Coordinated Investigations (FOCl) and is FOCl Contribution No. 100.

\section{LITERATURE CITED}

Bailey, K. B. (1989). Interaction between the vertical distribution of juvenile walleye pollock Theragra chalcogramma in the eastern Bering Sea, and cannibalism. Mar. Ecol. Prog. Ser. 53: 205-213

Bailey, K., Francis, R., Schumacher, J. (1986). Recent information on the causes of variability in recruitment of Alaska pollock in eastern Bering Sea: physical conditions and biological interactions. Int. No. Pac. Fish. Comm. Bull. 47 : 155-165

Bailey, K. B., Stehr, C. L. (1986). Laboratory studies on the early life history of the walleye pollock, Theragra chalcogramma (Pallas). J. exp. mar. Biol. Ecol. 99: 233-246

Bailey, K. B., Houde, E. D. (1989). Predation on eggs and larvae of marine fishes and the recruitment problem. Adv. mar. Biol. 25: 1-83

Bates, R. (1990). Estimation of the seasonal egg production and daily egg mortality for walleye pollock Theragra chalcogramma in Shelikof Strait, AK, during the years 1981, 1985, and 1986. NOAA NMFS Proc. Report 90-08, 114 p.

Boisclair, D., Leggett, W. C. (1988). An in situ experimental evaluation of the Elliott and Persson and the Eggers models for estimating fish daily ration. Can. J. Fish. Aquat. Sci. 45: 138-145

Daan, N., Rijnsdorp, A. D., Overbeeke, G. R. van. (1985). Predation by North Sea herring Clupea harengus on eggs of plaice Pleuronectes platessa and cod Gadus morhua. Trans. Am. Fish. Soc. 114: 499-506

Dwyer, D. A., Bailey, K. M., Livingston, P. A. (1987). Feeding habits and daily ration of walleye pollock (Theragra chalcogramma) in the eastern Bering Sea, with special reference to cannibalism. Can. J. Fish. Aquat. Sci. 44: 1972-1984

Eggers, D. M. (1977). Factors in interpreting data obtained by diel sampling of fish stomachs. J. Fish. Res. Bd Can. 34: 290-294

Elliott, J. M., Persson, L. (1978). The estimation of daily rates of food consumption for fish. J. Anim. Ecol. 47: 977-990

Francis, R. C., Bailey, K. B. (1983). Factors affecting recruit- ment of selected gadoids in the northeast Pacific and eastern Bering Sea. In: Wooster, W.S. (ed.) From year to year Washington Sea Grant, University of Washington, Seattle, p. 35-60

Haynes, E. B., Ignell, S. E. (1983). Effect of temperature on rate of embryonic development of walleye pollock. Theragra chalcogramma. Fish. Bull. U.S. 81: 890-894

Hinckley, S., Bailey, K. M., Picquelle, S. J., Schumacher, J. D., Stabeno, P. J. (1991). Transport, distribution, and abundance of larval and juvenile walleye pollock Theragra chalcogramma in the western Gulf of Alaska. Can. J. Fish. Aquat, Sci. 48: 91-98

Hollowed, A. B., Megrey, B. A. (in press). Gulf of Alaska walleye pollock: population assessment and status of the resource in 1989. In: Wilderbuer, T.K. (ed.) Condition of Groundfish Resources of the Gulf of Alaska in 1989. NOAA Tech. Memo.

Hunter, J. R. (1984). Inferences regarding predation on the early life stages of cod and other fishes. In: Dahl, E., Danielssen, D. S., Moksness, E., Solemdal, P. (eds.) The propagation of cod Gadus morhua L. Institute of Marine Research, Arendal, Norway, p. 533-562

Hunter, J. R., Kimbrell, C. A. (1980). Egg cannibalism in the northern anchovy, Engraulis mordax. Fish. Bull. U.S. 78: 811-816

Incze, L. S., Kendall, A. W. Jr, Schumacher, J. D., Reed, R. R. (1989). Interactions of a mesoscale patch of larval fish (Theragra chalcogramma) with the Alaska Coastal Current. Cont. Shelf Res. 9: 269-284

Kendall, A. W. Jr, Clarke, M. E., Yoklavich, M. M., Boehlert, G. W. (1987). Distribution, feeding, and growth of walleye pollock, Theragra chalcogramma, from Shelikof Strait, Gulf of Alaska. Fish. Bull. U.S. 85: 499-521

Kendall, A. W. Jr, Kim, S. (1989). Buoyancy of walleye pollock (Theragra chalcogramma) eggs in relation to water properties and movement in Shelikof Strait, Gulf of Alaska. In: Beamish, R. D., McFarlane, G. A. (eds.) Effects of ocean variability on recruitment and an evaluation of parameters used in stock assessment. Can. Spec. Publ. Fish. Aquat. Sci. 108: 169-180

Kim, S. (1987). Spawning behavior and early life history of walleye pollock. Theragra chalcogramma, in Shelikof Strait, Gulf of Alaska, in relation to oceanographic factors. Ph.D. thesis, University of Washington, Seattle

Kim, S., Gunderson, D. R. (1989). Cohort dynamics of walleye pollock in Shelikof Strait, Gulf of Alaska, during the egg and larval periods. Trans. Am. Fish. Soc. 118: 264-273

Livingston, P. A. (1989). Interannual trends in walleye pollock, (Theragra chalcogramma), cannibalism in the Eastern Bering Sea. In: Proceedings of the International Symposium on the Biology and Management of Walleye Pollock. Alaska Sea Grant, Anchorage, p. 275-296

MacCall, A. D. (1981). The consequences of cannibalism in the stock-recruitment relationship of planktivorous pelagic fishes such as Engraulis. In: Sharp, G. D. (ed.) Workshop on the Effects of Environmental Variation on the Survival of Larval Pelagic Fishes. Unesco, Paris, p. 201-220

Megrey, B. A. (1989a). Population dynamics of walleye pollock (Theragra chalcogramma) in the Gulf of Alaska. Ph.D. thesis, University of Washington, Seattle

Megrey, B. A. (1989b). Gulf of Alaska walleye pollock: population assessment and status of the resource as estimated in 1988. In: Wildebuer, T. K. (ed.) Condition of groundfish resources of the Gulf of Alaska in 1988. NOAA Tech. Memo. F/NWC-165, p. 1-53

Muigwa, N. M. (1989). Vertical distribution patterns of prespawning and spawning pollock (Theragra chalco- 
gramma) in Shelikof Strait. In: Proceedings of the International Symposium on the Biology and Management of Walleye Pollock. Alaska Sea Grant, Anchorage, p. 403-431

Ricker, W. E. (1954). Stock and recruitment. J. Fish. Res. Bd Can. 11: 559-623

Shelton, G. (1970). The regulation of breathing. In: Hoar, W. S., Randall, J. R. (eds.) Fish physiology. Academic Press, New York, p. 293-359

Smith, R. L., Paul, A. J., Paul, J. M. (1988). Aspects of energetics of adult walleye pollock, Theragra chalcogramma (Pallas), from Alaska. J. Fish. Biol. 33: 445-454

This article was submitted to the editor
Smith, R. L., Paul, J. M., Paul. A. J. (1989). Gastric evacuation in walleye pollock. Theragra chalcogramma. Can. J. Fish. Aquat Sci. 46: 489-493

Valdés, E. S., Shelton, P. A., Armstrong, M. J., Field, J. G (1987). Cannibalism in South African anchovy: egg mortality and egg consumption rates. S. Afr. J. mar. Sci. 5: 613-622

Williamson, N. J. (in press). Acoustic-midwater trawl surveys for walleye pollock in the Gulf of Alaska in 1989. In: Wilderbuer, $\mathrm{T}$ K. (ed.) Condition of groundfish resources of the Gulf of Alaska in 1989 NOAA Tech. Memo.

Manuscript first received: June 14, 1990

Revised version accepted: January 23, 1991 